\title{
WHITE-TAILED PTARMIGAN
}

Photographs by Geoff Holroyd, Box 1343, Banff, Alberta. TOL OC0

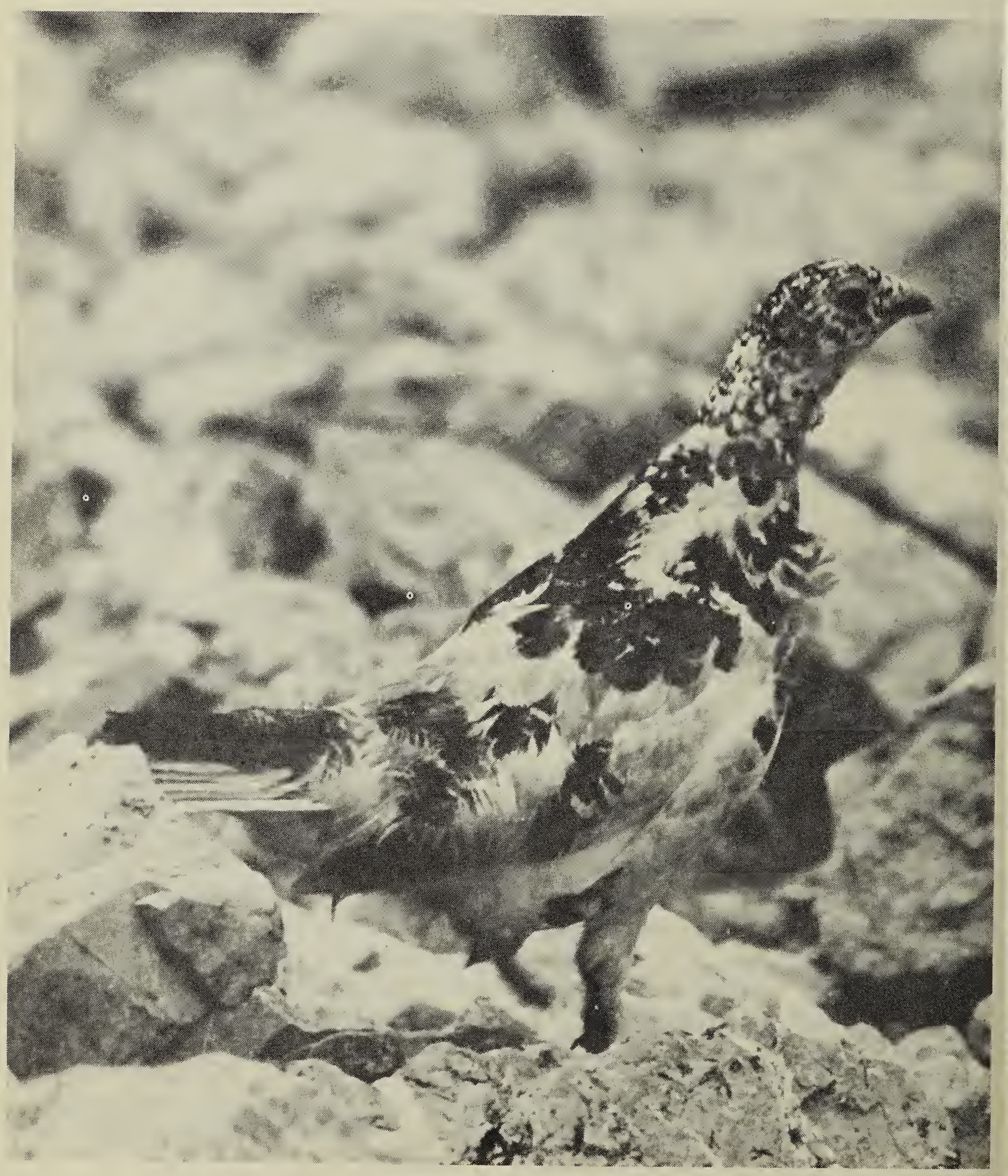


